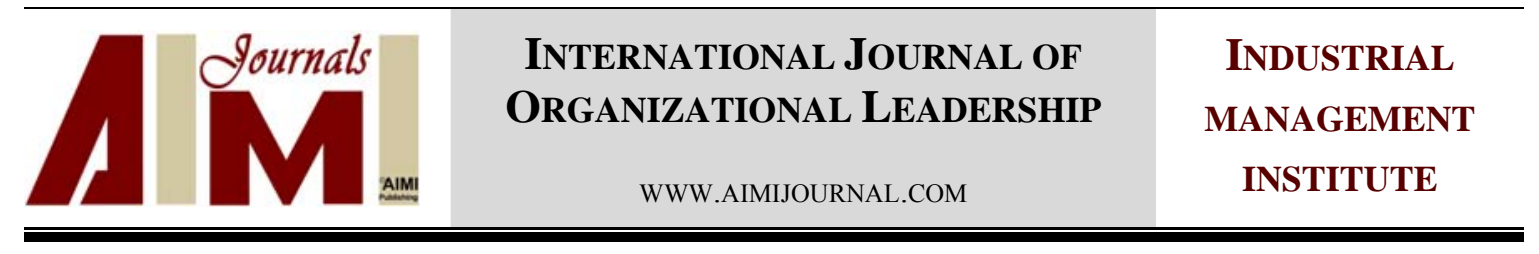

\title{
Servant leadership and organizational identity: The mediating role of job involvement
}

\author{
Mohsen Akbari ${ }^{1}$, Sayed Hesam Kashani ${ }^{2}$, Hani Nikookar ${ }^{3}$, Javad Ghaemi ${ }^{4}$ \\ ${ }^{1,3,4}$ University of Guilan, Iran \\ ${ }^{2}$ University of Isfahan, Iran
}

\begin{abstract}
Keywords:

Servant Leadership, Job Involvement,

Organizational Identity

Correspondence:

m.akbari@guilan.ac.ir

This study examines the relation between servant leadership and organizational identity and job involvement in Tax office of Guilan in Iran. One hundred and twenty two employees are participated in the study. For this purpose, a questionnaire with three parts was used. The questionnaire included three main sections, namely servant leadership, job involvement, and organizational identity. The analysis of the data obtained through the questionnaire indicated that servant leadership has significant effect on organizational identity and job involvement. Also, job involvement has positive effect on organizational identity. The findings, implications of the study, and suggestions for further research in this field are discussed in detail.
\end{abstract}

CAIMI Journals

\section{Introduction}

Organizational identity refers broadly to what members perceive, feel, and think about past, present, and future of their organization. In fact, organizational identity plays a pivotal role in adjusting behavioral norms of organization members. Managers take advantage of symbolic mechanisms in order to develop and confirm a distinctive organizational identity and this distinctive identity results in self-regulation in members of an organization to achieve 
performance goals, talent attraction, retention, fame, and security in the mind and helps people cope with ambiguous situations (Rahmanseresht \& Farhadinejad, 2010).

Organizational identity, as a competitive advantage for organizations, has recently attracted close attention of researchers and practitioners. It is an individual quality that makes an organization stand apart from other organizations. Understanding, developing, and strengthening the concept of organizational identity is of primary importance for managers, because employee's identification with an organization reduces their turnover, increases their positive organizational behavior consistent with the purposes of that organization, and ultimately helps them achieve the organization's intended purposes (Elsbach \& Kramer, 1996). Findings of studies underscore the fact that employees who identify themselves primarily with their organization usually have higher organizational commitment and are much less inclined to leave their jobs and the organization they work for than employees without such commitment (DeCninck, 2011). As a matter of fact, the important thing is that how leaders and managers of organizations can help their employees increase or construct a sense of organizational identity to benefit its considerable advantages. Simply put, servant leadership is a form of leadership in which servant leaders are those who focus on their followers, so that the followers are considered as one of the primary concerns of the organization. It allows staff to identify the organizations with the best leadership practices and benefit from advantages of organizational identity by constructs such as humility, service, reliability, and Agapao love.

Traditional theories of leadership were based on a hierarchical model in which an absolute power dictated the orders from top to down and the followers at the lower levels as a member of an organization were required to follow the orders. However, the changes in the environment have prompted many researchers to reconsider traditional theories. People in traditional structures are as servants for leaders while in the inverted pyramid leaders serve their followers. Inverted pyramid model can be regarded as the essence of servant leadership. In this model, leaders are the servants of their followers who see themselves at the bottom of organizational hierarchy. Servant leadership can be considered as an approach with a longlasting history that gradually revived and finally proposed as an ideal and evolutional approach toward responding to the growing needs of human resource development in the changing environment of business (Spears, 1996).

Job involvement is one of the most important factors that can lead to creation of organizational identity. In fact, it plays a mediating role in societies where servant leadership 
is a good option for developing job involvement. Job involvement is a degree in which an individual gets mentally, cognitively, and psychologically involved in his or her job and shows great interest in it (Paullay, Alligar, \& Stone-Romeo, 1994). Job involvement is related to job identity and organizational identity, thus, a job gives identity to individuals and organizations. These individuals would make great efforts to achieve organizational goals (Pferffer, 1994). On the other hand, some employees are job alienated and instead of flourishing in their jobs, they do other jobs or spend their time in vanity during the work at the organization (Seeman, 1959).

This study investigates the mediating role of job involvement in servant leadership and organizational identity. The next section presents the theoretical foundations and the literature and elaborates on the conceptual model and hypotheses. Next, the method is explained including population, statistical sample, and the instrument used in the study. Finally, it provides information about hypotheses testing, examining the effect of the dependent and independent variables and the mediator, and then it draws conclusions and provides suggestions for further research.

\section{Organizational Identity}

The concept of organizational identity was introduced by Albert and Whetten in 1985. They suggested that organizational identity represents the characteristics of an organization that its members perceive to be central, distinctive, and enduring in their organization. It seeks to answer to the question regarding the identity that who we are as an organization (Sillince, 2006). Organizational identity is a concept that describes the relationship between the individuals and the organizations in which they work. Experts in the field of organizational identity define it as a measure of members' perceived oneness with their organization, where people define themselves according to the characteristics of their organization (Hall \& Schneider, 1972). The foundation of this theory is built on the notion that the employees who affiliated with the organization exhibit cooperative behavior beyond their own organizational role. In other words, it is considered as a limit that members of the organization know themselves as part of organization and imagine their identity within the organizational framework and imagine organizational successes and failures as their own successes and failures (Eisenberger, Huntington, Hutchinson, \& Sowa, 1986). In a nutshell, research on organizational identity, as a critical factor in organizational life, shows that the employees 
who feel the same identity with their organizations display positive attitudes and behaviors in their workplace (Riketta, 2005).

\section{Servant Leadership}

The concept of servant leadership first was proposed by Robert Greenleaf in the "The Servant as Leader", a seminal paper that he published in 1970 (Spears, 1996). He viewed leadership as duties and responsibilities in servicing (Anderson, 2008). In this work, he defined the notion that the great leader is seen as a servant at first. It starts with a natural feeling that anybody wants to serve first. Then, this conscious choice creates a passion for leadership. The difference shows itself in the care that taken by the servant first and ensures that they meet people's necessary requirements. The most difficult tests to administer are: Have those been served grow as persons? Have those been served become healthier, wiser, freer, more independent, and more likely to be the servant of the people? Drury (2004) defined servant leadership as an understanding and experience of leadership that considers the interests of followers superior to leaders' personal interest. Spears (1996) defined servant leadership as a new kind of leadership model, a model that puts serving others first priority. Servant leadership has a growing emphasis on servicing to others, a holistic approach to work, promoting a sense of integration and participation in the decision-making power. In general, the premise of a servant leadership is the leader who seeks to serve and this serving is an essential component of a leader (Patterson, 2003). Larry Spears identified ten major leadership characteristics which are central to the development of a servant-leader. These characteristics are listening, empathy, healing, awareness, persuasion, conceptualization, foresight, stewardship, commitment to growth of people, and building community (Omoh, 2007). He believed that these ten characteristics of servant leadership are comprehensive, but other researchers and scholars in this field added some new features to them. Based on this approach, great leaders were great servants and this has been the key element to their success. Drucker (1981) believed that the future organizations will be organizations that equality, equity, fairness, and justice are emphasized. In organizations that did not use the terms superior and subordinate, the value of the employees was the same as the value of managers (Horsman, 2001). Patterson (2003) presented the functional theory of servant leadership as a logical extension. Stone, Russell, and Patterson (2004) suggested that transformational leaders' primary concern is the organization's goals, while servant leaders focus on followers. According to Patterson's theories (2003), servant leadership constructs identified as Agapao 
love, humility, altruism, trustworthiness, vision, and empowerment. This paper uses four types of servant leadership constructs that Gholipour and Hazrati (2009) found through conducting exploratory factor analysis. These constructs which explain 72 percent of the total variance in servant leadership are serving, humility, reliability, and Agapao love. They investigated Patterson's servant leadership model and identified several factors, then they localized these factors to four types which their details are briefly described as follows.

Serving is located in the heart of servant leadership (Greenleaf, 1977). Hence, leaders are required to show this value in their behaviors, attitudes, and values. A good leader is one who has the eagerness and willingness to serve others and consequently others serve him (Cardona, 2000). Serving forms the central core of servant leadership and is considered a moral imperative. Unfortunately, based on the studies conducted to date, it can be observed that when we get to choose between self-interest and serving others, i.e., altruism, we usually opt for self-interest more. A leader who aims to serve others, he is assumed to provide needed resources for their success. They serve others through providing information, material resources, time, attention and consideration, and making their duties and jobs more meaningful. Servant leaders make their followers ready to accept serving people with open arms. Personnel have a strong sense of responsibility towards those who serve them. Despite the importance of serving, less attention has been paid to the role of serving in servant leadership and it is because of this gap that each individual has always been working according to his own logic of self-interest and there would be no place for the interests of others. Although the idea of a leader who serves others is different from the idea of a servant who has leadership, both of them combine serving with leadership (Dennis, 2004).

According to Sandage and Wiens (2001), humility does not mean that a person pays attention exclusively to self but also to others and considers their abilities and talents. Humility does not mean that a person ignores himself, but rather humility means that one feels no superior or inferior to others. Servant leaders represent these characteristics by giving priority to the needs of others and their followers (Dennis, 2004).

Stable trust and confidence based on honesty are abilities or characters of a person. It is the passion of the group to recent initiatives of another group. Building and maintaining trust is essential to an organization. The presence of trust in the workplace is one of the most influential factors in connection with follower-leader, leadership effectiveness, and productivity. It, also, provides an excellent base for leadership. In an organization where fear dominates, trust is undermined and as a result productivity is decreased. Russell (2001) 
considered values of honesty and competence as a framework to build organizational and interpersonal trust and claimed that this trust is the essence of servant leadership. In addition, he believed that leaders, who act on what they say, are leaders that create the trust. Furthermore, the leaders' interest and willingness to get input from others, can lead to increased trust, and as a result their followers show themselves more willing to follow the leaders who benefit from reliability and stability (Dennis, 2004).

Vinson (2002) stated that the relationship between the follower and servant leader is founded on the love and this love is a kind of moral, social, and intellectual one. It causes the leaders do not regard everyone only as a means to achieve their goals, but rather see each person as a complete human being with different needs, desires, and aspirations (Dennis, 2004).

Job involvement is a degree in which an individual gets involved mentally, cognitively, and psychologically in his job and shows his desire and interest in it (Paullay, Alliger, \& Stone -Romeo, 1994). When a job is entrusted to a person, he enjoys his job and never gets tired. Employees' job involvement is not an easy task for managers because self-alienation and alienated labor are natural consequences of organizational life. Accordingly, majority of people have become alienated from their jobs instead of developing themselves and their careers.

Identifying the causes and consequences of job involvement is important for managers because it relates effectively to employees' job motivation, job satisfaction, and their organizational citizenship behavior. A meta-analysis on 87 studies with 27,925 samples revealed that both job involvement and job satisfaction are strongly related. Additionally, job involvement has a positive relationship with variables such as organizational commitment and organizational citizenship behavior (Rotenberry \& Moberg, 2007), leading to customer satisfaction, profitability, and productivity (Emery \& Barker, 2007) and also has a negative correlation with absenteeism and turnover (Brown, 1996).

\section{Review of Literature}

Based on studies conducted to date, it can be argued that, to my best knowledge, there is a gap in the literature investigating the effect of servant leadership on organizational identity and servant leadership and job involvement and research in this realm is quite new. In order to shed more light on this issue and understand the issue, the following paragraphs provide the number of studies that are related to this subject. 
Kharrazi, Mirkamaly, and Turki (2013) found that there was a significant positive correlation $(r=0.58)$ between servant leadership and job satisfaction of employees. Stepwise regression analysis results showed that among the components of servant leadership, the leadership was the strongest predictor of job satisfaction that alone would predict 38 percent of the variance in job satisfaction. In assessing the characteristics of organization servant leadership and job satisfaction of employees, there was no significant difference in the age and education level.

Gholipour, Pourezzat, and Hazrati (2009b) conducted a research and concluded that there was a strong relationship among servant leadership, trust, and empowerment. The findings of this study suggest that there is a statistically significant difference between employees and managers in perception of servant leadership.

Mohammadi, Hazrati, and Jafari (2013) observed that there was a positive and significant relationship between the staff's evaluation of atmosphere based on components of spirituality in the workplace and managers' assessment based on the serving components. They stated that the improvements in workplace spirituality strengthen serving values of leaders.

\section{Conceptual Model}

Conceptual model is a model based on the theoretical relationship between the factors and variables affecting the subject of research. Figure 1 shows the conceptual model of the current study.

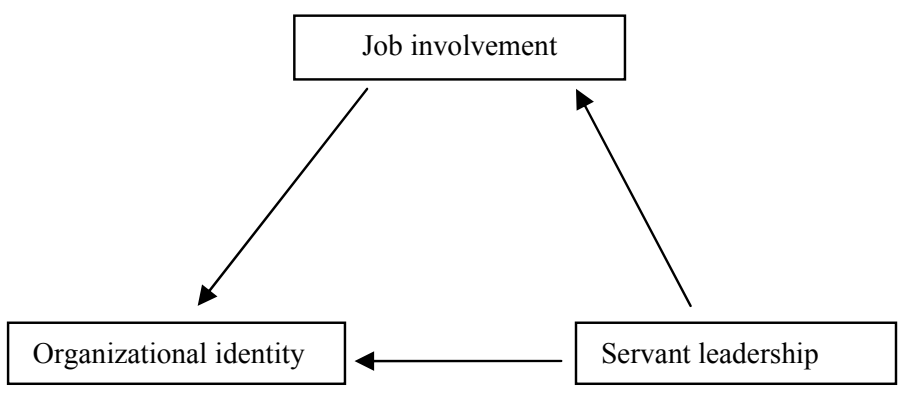

Figure 1. Conceptual model of research

The above model suggests that servant leadership directly affects organizational identity and indirectly when mediated by job involvement. In addition, job involvement, also, has direct effects on organizational identity. 


\section{Research Question and Hypotheses}

The study specifically aimed to answer the following question:

- Does servant leadership have a significant effect on job involvement and organizational identity?

Based on the conceptual model and the aim of the study, it is postulated that:

- H1: Servant leadership has a positive impact on job involvement of employees.

- H2: Servant leadership has a positive impact on organizational identity.

- H3: Job involvement has a positive impact on organizational identity of employees.

\section{Method}

For the purpose of this study, 122 employees were selected from tax office of Guilan, Iran. A questionnaire including 28 statements about servant leadership, job involvement, and organizational identity was employed. All the items of the questionnaire were adapted from different related questionnaires used in studies (e.g. Ashforth \& Mael, 1989; Gholipour \& Ezzati, 2009; Patterson, 2003) and adapted for the purpose of this study. It measured participants' frequency of actual use by means of five-point Likert scale. The variables in this questionnaire were serving, humility, trust, and Agapao love which, as already highlighted, explain 72 percent of the variance in servant leadership. To confirm the validity, the researcher asked opinions of some experts in the field to rate the instrument's efficacy. The validated questionnaire was given to a pilot group in order to check its reliability and participants' understanding of the items of the questionnaire. Data of the questionnaire from the pilot group were analyzed for determining an internal consistency reliability coefficient through Cronbach Alpha. Based on the data gathered, the reliability coefficient alpha was calculated to be 0.7 , which is considered a high level of reliability.

The design of this study is descriptive in nature. To examine the research question, one sample t-test and structural equations modeling were used. The obtained data from the instrument were put into SPSS 20 and Lisrel 8.8 for data analysis. Table 1 shows the coefficients for the path analysis and confirmatory factor analysis relating to the conceptual model. 
Table 1

Cronbach's Alpha Coefficient Associated with each Dimension

\begin{tabular}{lcc}
\hline Dimension & Number of Questions & The Cronbach's Alpha Coefficient \\
\hline Serving & 6 & 0.71 \\
Humility & 7 & 0.78 \\
Trust & 10 & 0.84 \\
Agapao Love & 5 & 0.73 \\
Organizational Identity & 6 & 0.82 \\
Job Involvement & 20 & 0.73 \\
\hline
\end{tabular}

\section{Results}

To examine the research question, first we needed to be aware of the proper fitness of the model and then test assumptions. Table 2 shows that the fit of the present study is in a good condition.

Table 2

Measures of Fit

\begin{tabular}{lccc}
\hline Measures of Fit & Quantity & Measures of Fit & Quantity \\
\hline X2/df & 1.35 & CFI & 0.96 \\
GFI & 0.97 & NFI & 0.98 \\
AGFI & 0.95 & RMSEA & 0.04 \\
\hline
\end{tabular}

Table 3 depicts a summary of the hypothesis test.

Table 3

Results of Hypotheses Testing

\begin{tabular}{cllcccc}
\hline Number of Hypothesis & Dependent Variable & Independent Variable & T-Value & Error Rate & Beta & Test Results \\
& & & & & \\
\hline First & Servant Leadership & Organizational Identity & 13.46 & 0.05 & 0.72 & Hypothesis Support \\
Second & Servant Leadership & Job Involvement & 9.56 & 0.05 & 0.96 & Hypothesis Support \\
Third & Job Involvement & Organizational Identity & 15.32 & 0.05 & 0.26 & Hypothesis Support \\
\hline
\end{tabular}

Based on Table 3, servant leadership has a meaningful and positive effect on organizational identity because significant amount is less than 0.05 . Therefore, it can be argued that by increasing the servant leadership, organizational identity scores also increased and improved.

In order to assess the impact of servant leadership on job involvement further analysis was conducted. It showed that servant leadership has a meaningful and positive effect on job involvement. Table 3 shows that with increasing job involvement, organizational identity scores increased and improved. Therefore, job involvement has a meaningful and positive impact on organizational identity $(p<0.05)$.

Figure 2 depicts that all factor loadings are more than 0.3 and the questionnaire has sufficient validity. Meanwhile, all assumptions are significant at the 0.95 percent level of confidence, and factor loadings of all the variables and their associated t-values are higher than 1.96. Figure 2 also suggests that Agapao love is the best representation of the servant 
leadership. In order to check the status of variables, t-test was run. To perform this test, it was assumed the following:

$\mathrm{H}_{0}$ (null hypothesis): Test Value $=\mu$

$\mathrm{H}_{1}$ (alternative hypothesis): Test Value $=\mu$

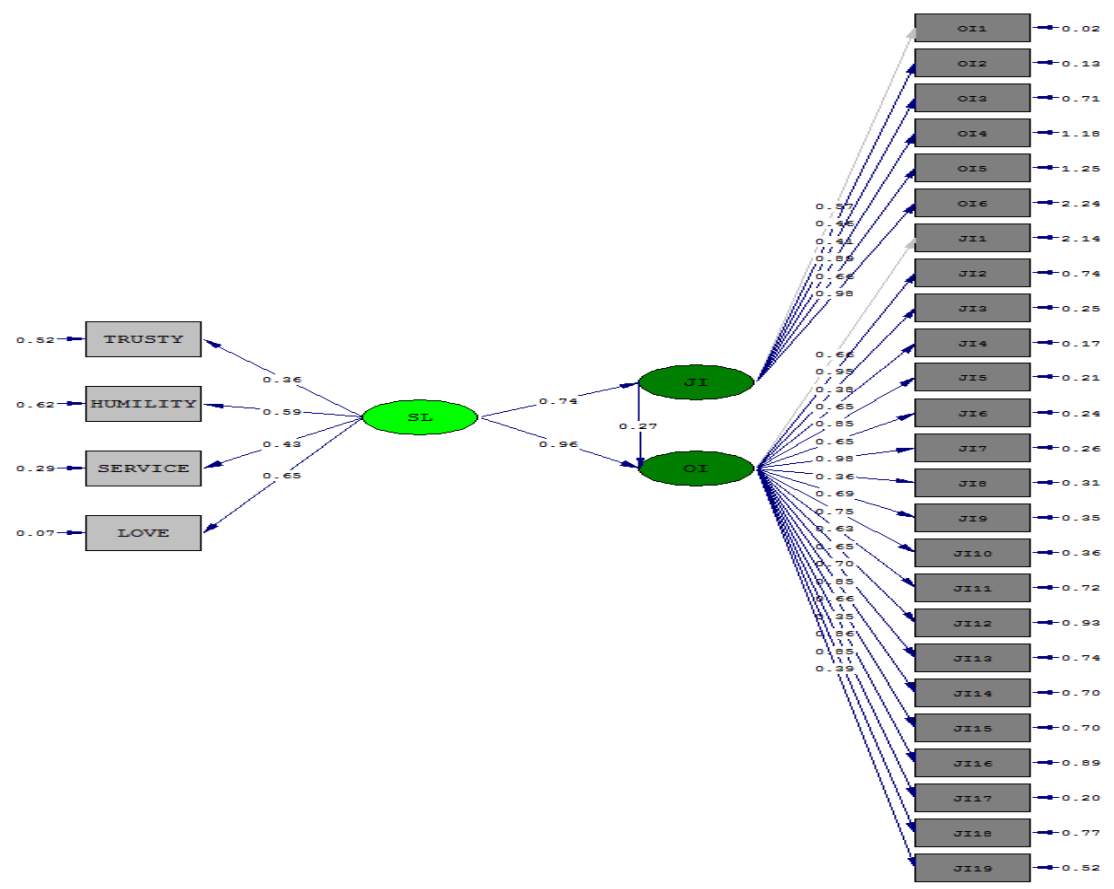

Figure 2. Structural equation model (standardized coefficients)

According to Table 3, if the significance level is more than error level $(p>0.05)$, it will confirm the null hypothesis and reject alternative hypothesis. This means that the average is equal to the value of the test. If the significance level is less than error level $(p<0.05)$, it will confirm the alternative hypothesis and reject null hypothesis and it is concluded that the average is not equal to the value of the test. However, to understand the mean value is less or more than the test value, we should look at upper and lower limit of the confidence interval; So that, if the upper limit and lower limit are positive, the mean value of the test is higher than the value of the test, if the upper limit and lower limit are negative, the mean value of the test is less than the value of the test. Finally, if the lower limit is negative and upper limit is positive, the value of the test is not different from the mean value of the test. The significance level in this study is much larger than the conventional 0.05. The reason for selecting number 18 is that the lowest score in this class is 6 (because the number of questions are 6 and when it is multiplied by 1 it becomes 6 ) and the highest score is 30 
(because the number of questions are 6 and when it is multiplied by 5 it becomes 30 and 30 plus 6 is equal to 36 and If we divide this number by 2, we obtain 18 -similar practices which are used for other variables).

Table 4

One-sample t-test for Variables of Servant Leadership and Job Involvement

\begin{tabular}{|c|c|c|c|c|c|c|}
\hline \multirow{2}{*}{ Serving } & \multicolumn{4}{|c|}{ Test Value 18} & \multicolumn{2}{|c|}{$95 \%$ Confidence Interval } \\
\hline & $\mathrm{t}$ & $\mathrm{df}$ & Sig & $\begin{array}{c}\text { Mean } \\
\text { Variance }\end{array}$ & Lower Limit & Upper Limit \\
\hline 1 & 10.96 & 121 & 0.00 & 4.86 & 3.98 & 5.73 \\
\hline \multirow[b]{2}{*}{ Humility } & \multicolumn{4}{|c|}{ Test Value 21} & \multicolumn{2}{|c|}{$95 \%$ Confidence Interval } \\
\hline & $\mathrm{t}$ & $\mathrm{df}$ & Sig & $\begin{array}{c}\text { Mean } \\
\text { Variance }\end{array}$ & Lower Limit & Upper Limit \\
\hline 2 & 4.9 & 121 & 0.00 & 2.55 & 1.52 & 3.59 \\
\hline \multirow[b]{2}{*}{ Trust } & \multicolumn{4}{|c|}{ Test Value 30} & \multicolumn{2}{|c|}{$95 \%$ Confidence Interval } \\
\hline & $\mathrm{t}$ & $\mathrm{df}$ & Sig & $\begin{array}{c}\text { Mean } \\
\text { Variance }\end{array}$ & Lower Limit & Upper Limit \\
\hline 3 & 0.19 & 121 & 0.23 & -01.01 & -2.7 & 6.6 \\
\hline \multirow{2}{*}{ Agapao Love } & \multicolumn{4}{|c|}{ Test Value 15} & \multicolumn{2}{|c|}{$95 \%$ Confidence Interval } \\
\hline & $\mathrm{t}$ & $\mathrm{df}$ & Sig & $\begin{array}{c}\text { Mean } \\
\text { Variance }\end{array}$ & Lower Limit & Upper Limit \\
\hline 4 & 13.43 & 121 & 0.00 & 5.04 & 4.23 & 5.78 \\
\hline \multirow{2}{*}{ Job Involvement } & \multicolumn{4}{|c|}{ Test Value 18} & \multicolumn{2}{|c|}{$95 \%$ Confidence Interval } \\
\hline & $\mathrm{t}$ & $\mathrm{df}$ & Sig & $\begin{array}{c}\text { Mean } \\
\text { Variance }\end{array}$ & Lower Limit & Upper Limit \\
\hline 5 & 7.73 & 121 & 0.00 & 3.41 & 2.54 & 4.29 \\
\hline \multirow{3}{*}{ Organizational Identity } & \multicolumn{4}{|c|}{ Test value $=18$} & \multicolumn{2}{|c|}{$95 \%$ Confidence Interval } \\
\hline & $\mathrm{t}$ & df & Sig & $\begin{array}{c}\text { Mean } \\
\text { Variance }\end{array}$ & Lower Limit & Upper Limit \\
\hline & 8.18 & 121 & 0.00 & 10 & 7.58 & 12.42 \\
\hline
\end{tabular}

Table 4 shows that the staffs' significance level is less than error level. According to the upper and lower limits, it is clear that the mean value is greater than the test value. It indicates that tax office staffs of Guilan have great humility and the significance level is less than error level $(p<0.05)$, it will confirm the alternative hypothesis and reject null hypothesis. According to the upper and lower limits, it is clear that the mean value is greater than the test value (i.e., 21). It reveals that tax office staff of Guilan have an average level of trust and the 
significance level is less than error level $(p<0.05)$. According to the upper and lower limits, it is clear that the mean value is equal to test value (i.e., 30).

Furthermore, they have great level of Agapao love, and the significance level is less than error level $(p<0.05)$. According to the upper and lower limits, it is clear that the mean value is more than the test value (i.e., 15). They have great job involvement, and the significance level is less than error level $(p<0.05)$. Based on the upper and lower limits, it is clear that the mean value is more than the test value (i.e., 18). As shown in Table 5, the staff's organizational identity can be seen in the upper limit and it can have many benefits for organizations such as increasing effectiveness and efficiency, increasing organization profit, reducing staff turnover and mobility, and reducing the costs associated with hiring and training new employees.

\section{Discussion}

Efforts to develop and strengthen organizational identity are of utmost amportance for managers because identifying with groups and organizations reduces staff turnover, increases the positive behavior and aligns with organizational goals, and ultimately increases the achievement of organizational goals. Despite many researches in relation to organizational identity, little knowledge exists about the factors that affect the formation. This paper aims to investigate the concept of organizational identity; it also examines the factors contributing to the formation of it and assesses the relationship of them to their organizational identity. In general, theories of identity refer to the fact that subjects introduce themselves to others through different groups that are members (working group, organization, business, or profession). In this study, structural equation modeling support the existence of a causal relationship between servant leadership and organizational identity $(t=9.5, \beta=0.72)$, servant leadership and job involvement $(\mathrm{t}=6.5, \beta=0.96)$, and job involvement and organizational identity $(\mathrm{t}=13.5, \beta=0.26)$. It can be seen that all aspects of the supreme leadership, that is, service, humility, trust, and Agapao love have positive and significant impact on job involvement and organizational identities.

Senior management of an organization plays an important role in shaping the organizational identity. The ability of managers to make appropriate and effective strategic decisions in order to improve the situation of organizations, competencies, credibility, reputation and expertise causes employees to involve more in organization identity. Measures like training courses for managers and acquainting them with methods, techniques, and 
decision making skills improve the ability of managers to make strategic decisions, especially in times of crisis. On the other hand, avoiding one-sided biases and dogmatic functions in the election of directors, studying their performance in previous positions, investigating their reputation in the community in order to find the qualified and competent people and determining the desired properties and characteristics of organization identity, causes managers to be selected based on their compatibility with these properties and be provided the formation of a coherent and consistent organization.

In addition, job involvement has positive correlation with commitment, organizational citizenship behavior, motivation, and positive performance and has negative correlation with absenteeism and turnover. Job involvement is also associated with the identification. The involved individual usually knows his job as introducer for himself (Kahn, 1999). Thus, with respect to the benefits of job involvement for organizations, and on the other hand, servant leadership which has a positive relationship with job involvement, top managers of most organizations are recommended to develop serving in order to take advantage of job involvement.

Job involvement has a significant positive impact on organizational identity. Greenleaf (1977) stated that management schools failed to fulfill their responsibility to prepare individuals for leadership roles in society. Chronic crisis of governance and inclusive unworthiness of organizations in overcoming the expectations of their stakeholders is now considered as a global crisis. The servant leadership topic is important for all organizations so it is suggested that leaders of organizations take this topic as a serious business and foster it as much as possible in order to improve organizational identification and job involvement. Without a shadow of doubt, job involvement has undeniable benefits and it is associated with organizational identity. It also has significant benefits for organizations. So the servant leadership can serve as a bridge to cross today's turbulent and changing environment. In conclusion, it should be highlighted that researchers should conduct further studies investigating various aspects of this field of study in different contexts.

\section{References}

Anderson, J. (2008). The writings of Robert K. Greenleaf: An interpretive analysis and the future of servant leadership. Paper presented at the Servant Leadership Research Roundtable, Regent University, Virginia Beach, VA.

Ashforth, B. E., \& Mael, F. (1989). Social identity theory and the organization. Academy of Management Review, 14(1), 2039.

Bergami, M., \& Bagozzi, R. P. (2000). Self categorization, affective commitment and group self-esteem as distinct aspects of social identity in the organization. British Journal of Social Psychology, 39(4), 555-577. 
Brown, S. P. (1996). A meta-analysis and review of organizational research on job involvement. Psychological Bulletin, 120(2), 235-255.

Cardona, P. (2000). Transcendental leadership. The Leadership and Organization Development Journal, 21(4), 201-206.

DeConinck, J. (2011). The effects of ethical climate on organizational identification, supervisory trust, and turnover among sales people. Journal of Business Research, 64(6), 617-624.

Dennis, R. S. (2004). Servant leadership theory: Development of the servant leadership theory assessment instrument (Unpublished doctorial dissertation). Regent University, Virginia Beach, VA.

Drury, S. L. (2004). Servant leadership and organizational commitment: Empirical findings and workplace implications. Proceedings of the Servant Leadership Research Round table of Regent University, School of Leadership Studies, Virginia Beach, VA.

Eisenberger, R., Huntington, R., Hutchison, S., \& Sowa, D. (1986). Perceived organizational support. Journal of Applied Psychology, 71(3), 500-507.

Elsbach, K. D., \& Kramer R. M. (1996). Members' responses to organizational identity threats: Encountering and countering business week rankings. Administrative Science Quarterly, 41(3), 442 - 476.

Emery, C. R., \& Barker, K. J. (2007). Effect of commitment, job involvement and teams on customer satisfaction and profit. Team Performance Management, Learning and Pedagogy, 13(3/4), 90-101.

Gholipour, A. (2007). Management of organizational behavior ( $1^{\text {st }}$ ed.). Tehran: SAMT Publication.

Gholipour, A., \& Hazrati, M. (2009a). Explanation of measurement tools of servant leadership in public organizations. Journal of Public Administration, 3, 5-27.

Gholipour, A., Pourezzat, A., \& Hazrati, M. (2009b). The effect of servant leadership on organizational trust and empowerment in public organizations. Journal of Public Administration, 1(2), 103-118.

Greenleaf, R. F. (1977). Servant leadership: A journey into nature of legitimate power and greatness. Mahwah, NT: Paulist press.

Hall, D. T., \& Schneider, B. (1972). Correlates of Organizational Identification as a function of career pattern an organizational type. Administrative Science Quarterly, 17(3), 340-350.

Kahn, W. A. (1999) Psychological conditions of personal engagement and disengagement at work. Academy of Management Journal, 33(4), 692-724.

Kharazi, S. K., Mirkamaly, S. M., \& Turki, A. (2013). Servant leadership and job satisfaction. Journal of Public Administration Perspective, 4(14), 87-116.

Lodahl, T. M., \& Kejner, M. (1965). The definition and measurement of job involvement. Journal of Applied Psychology, 49(1), 24-33.

Mael, F., \& Ashforth, B. E. (1992). Alumni and their alma mater: A partial test of the reformulated model of organizational identification. Journal of Organizational Behavior, 13(2), 103-123.

Mohammadi, F., Hazrati, M., \& Jafari, A. (2013). Investigating the relationship between workplace spirituality and staffs perceptions of servant leadership. Journal of Public Administration, 20, 145-164.

Omoh, O. D. A. (2007). Analysis of servant leadership characteristics: A case study of community college president (Unpublished doctoral dissertation). Capella University, Minnesota, U.S.

Patterson, K. (2003). Servant leadership: A theoretical model (Unpublished doctoral dissertation). Regent University, Virginia Beach, VA.

Paullay, I. M., Alliger. G. M., \& Stone -Romeo, E. F. (1994). Construct validation of two instruments designed to measure job involvement and work centrality. Journal of Applied Psychology, 79(2), 224-228.

Pfeffer, J. (1994). Competitive advantage through people: Unleashing the power of the work force. Boston: Harvard Business School Press.

Puusa, A. (2006). Conducting research on organizational identity. Electronic Journal of Business Ethics and Organization Studies, 11(2), 24-28.

Rahmansresht, H., \& Farhadinejad, M. (2010). A review of the relationship between organizational identity and commitment. Journal of Human Resources, 11(2), 37-45.

Rotenberry, P.F., \& Moberg, P. J. (2007). Assessing the impact of job involvement on performance. Management Research News, 30(3), 203-215.

Russell, R. F. (2001). The role of values in servant leadership. Leadership \& Organization Development Journal, 22(2), 7683. 
Sandage, S. J., \& Wiens, T. W. (2001). Contextualizing models of humility and forgiveness: A reply to Gassin. Journal of Psychology and Theology, 29, 201-211.

Seeman, M. (1959). On the meaning of alienation. American Sociological Review, 24(4), 783-791.

Sillince, J. A. (2006). Resources and organizational identities: The role of rhetoric in the creation of competitive advantage. Management Communication Quarterly, 20(2), 186-212.

Spears, L. (1996). Reflections on Robert K. Greenleaf and servant- leadership. Leadership \& Organization Development Journal, 17(7), 33-35.

Spears, L.C. (2010). Character and servant leadership: Ten characteristics of effective, caring leaders. The Journal of Virtues \& Leadership, 1(1), 25-30. 